TANULMÁNYOK 2020/1. Bölcsészettudományi Kar, Újvidék

STUDIJE 2020/1. Filozofski fakultet, Novi Sad

STUDIES 2020/1. Faculty of Philosophy, Novi Sad

ETO: 37.04

ORIGINAL SCIENTIFIC PAPER

$73.04-053.2$

7.03 '02

DOI: $10.19090 / \mathrm{tm} .2020 .1 .99-125$

A kézirat leadásának időpontja: 2020. január 23.

Közlésre elfogadva: 2020. május 30.

\author{
TÁMBA Renátó \\ Reménysugár Habilitációs Intézet \\ Budapest, Magyarország \\ trenato87@gmail.com
}

\title{
NEVELÉSI JELENETEK, GYERMEKPORTRÉK ÉS ERÓSZ-FIGURÁK A KÉSŐ KLASSZIKUS KORI ÉS A HELLENISZTIKUS GÖRÖG SZOBRÁSZATBAN
}

\author{
Vaspitne scene, portreti dece i likovi Erosa u poznoj klasičnoj \\ i helenističkoj skulpturi
}

\author{
Educational Scenes, Child Portraits and Eros Figures \\ in Late Classical and Hellenistic Greek Sculpture
}

Tanulmányomban a hellenisztikus görög szobrászat gyermekportréinak, gyermek Erószfiguráinak, illetve diádikus kapcsolatot bemutató, zsáner jellegű gyermekábrázolásainak bemutatására törekszem, az alkotások mögött húzódó gyermekszemléleti mintázatok, főbb gyermekkor-, társadalom- és eszmetörténeti szólamok feltárására törekedve. Írásomban a gyermekkor-történeti ikonográfia módszertani eszköztárát használom fel, a Panofsky-féle ikonográfiai-ikonológiai modell mellett jelen esetben elsősorban a schneideri társadalomtörténeti megközelítést, a vizuális antropológia, a vizuális szociológia és a vizuális kommunikáció elemzési szempontjait érvényesítve az elemzések során. Vizsgálatom célja, hogy - a Tanulmányok 2019/1. számában megjelent Gyermekjelenetek a hellenisztikus görög szobrászatban címú írásom (Támba 2019, 101-122) mintegy folytatásaként - feltérképezhessem a kor gyermekábrázolásai által magukban hordozott eszmei-társadalmi irányú jelentéstartalmakat, kulturális utalásokat, melyek egyfajta, az individuum problémái iránt érdeklődő új bölcseleti érzékenység munkálására utalnak.

Kulcsszavak: hellenizmus, gyermekszemlélet, ikonográfia-ikonológia, individualista-naturalista ábrázolás, gyermekportré

\section{Gyermekkor és gyermekábrázolás a hellenizmus korában}

A hellenisztikus birodalmak korában Nagy Sándor elképzelései nyomán a hellén civilizáció határai immár a Közép-Keletig terjedtek (Hegyi et al. 2002, 312), Isokratés és Arisztotelész koncepciójának megfelelően a hellén müveltség 
vált az ember megítéltetésének fő mércéjévé (Bengtson 2009, 54). Ezzel együtt azonban megszünt a poliszok autonómiája, a városok alárendelődtek az állami hatalomnak (Hegyi et al. 2002, 314), s ebből fakadóan az egyén megszünt cselekvés-befolyásoló tényező lenni (Castiglione 1996, 21). A poliszdemokrácia elsorvadásával az individuum mindinkább elidegenedett a societastól (Castiglione 1996, 7), hiszen a hellenisztikus monarchiákat már nem tudta hazájának tekinteni (Hoffmann 2009, 62). Érdeklődése mindinkább az individuális léttartományok felé fordult (Castiglione 1996, 22), így a klasszikus erkölcsök és a kalokagathia eszményének helyébe olyan új, érzékenységet sugalló értékek kerültek, mint az emberbarátiság, a jóindulat és a szelídség (vesd össze Hauser 1968, 74). A korszak filozófiai irányzatai is az egyéni boldogulásban keresték az élet célját (Castiglione 1968, 219), így Epikurosz a közösségi élettől visszavonult életmódot javasolt (Bengtson 2009, 58) a lélek zavartalan állapotának elérése céljából (Falus 2005), a cinikusok a polgári értékek és a vagyon megtagadására szólítottak fel a társadalomtól való függetlenedés céljából (Zamarovsky 1980, 312), pusztán a sztoikusok hangsúlyozták a természettel összehangolt, az erkölcsi jóság által vezérelt élet kívánalmát (Long-Sedley 2014, 484, 513), az isteni világkormányzás eszméjének jegyében (Bengtson 2009, 56). Bármily népszerű is volt világtestvériségre vonatkozó elképzelésük (Bengtson 2009, 55), a klasszikus értékeket megkérdőjelező új bölcseleti reflexiók átfogóan kiterjedtek a mindennapi gondolkodásra, s így a gyermekkorról való gondolkodásra is, ösvényt vágva a gyermekhez forduló, az individuális lét problematikája felé nyitott gyermekszemlélet irányába.

Hiszen Plutarkhosz - retrospektívnak is tekinthető - gyermekségteóriájában már a családi nevelés, az apai kíméletesség jelentőségére, a szoptatás és a kötődés kapcsolatának fontosságára, valamint a gyermek lelki-fizikai teherbírásának figyelembevételére irányítja a figyelmet (French 1998, 53-54; Fináczy 1922, 184). A hellenisztikus bölcselők írásaiból kitűnik a gyermeki természet nüánszai iránti aprólékos érdeklődés, bár már Pindarosz ódáiban (French 1998, 51) és az Îliászban is részletekbe menő leírásokat találunk a gyermekkorról, egyrészt a gyermekhez fordulás mozzanatáról (French 1998, 57), másrészt pedig a gyermek esetlegességének, gyámoltalanságának, befejezetlen voltának felismeréséről tanúskodva. Hiszen a görögök a végtagok formálhatóságára vonatkozó elképzelésükkel igazoltnak vélték a testalkat és az értelmi karakter formálhatóságára vonatkozó felfogásukat, ezáltal szolgáltatva igazolási alapot a tanítás jelentőségéről, valamint a gyermek erkölcsi befolyásolhatóságáról, tudatlanságáról kialakított elképzelésüknek. Mindazonáltal a gyermek az irodalomban legtöbbször mégis ártatlan, szeretetre méltó, vidám, ugyanakkor bátortalan teremtésként jelenik meg (French 1998, 51), aki ráadásul engedelmességével 
és önuralmával gyakran eleget tett a vele szemben támasztott nevelési követelményeknek (French 1998, 52). A kalokagathia eszményének jegyében a gyermeknek a derekasság (areté) elérésére kellett törekednie, amely pedig csakis a komplex múzsai és gümnasztikai nevelés révén valósulhatott meg (Pukánszky 2001, 42; Fináczy 1922, 80), a paideia rendszerén keresztül (Németh 2004, 18; Hoffmann 2009, 73), mely a hellenizmus korában - a vérségi kötelék identitásképző erejének eljelentéktelenedéséből fakadóan - még hangsúlyosabbá vált (Hoffmann 2009, 63). Miképp Isokratés hirdette, az új korszakban a hellénné válás fő feltétele immár a komplex müveltség elsajátítása volt, melynek meghatározó eleme - annak értelmet, erkölcsöt és jellemet egyszerre formáló hatása okán - a retorika volt (Hoffmann 2009, 272; Fináczy 1922, 50-51), s az ékesszólás jelentőségére utaló motívumok a korszak irodalmában és művészetében egyaránt megjelentek, ideértve a gyermekábrázolásokat is.

Mint utaltunk rá, a poliszdemokrácia elsorvadásának következtében az egyetemes igazságosságba és fátumba vetett hitet az irodalomban leváltotta az esetlegesség és a véletlenszerűség mozzanata (Hauser 1968, 75), s ehhez hasonlóan a szobrászatban az idealizált atléta- és héroszábrázolás kontraposzton és harmónián nyugvó, totalitásélményt kifejező vizuális nyelvének helyébe egy mozgalmas, szenvedélyes ábrázolásmód lépett (Castiglione 1996, 61-62), tükröztetve a poliszdemokrácia rendíthetetlen eszmei egységének (Hauser 1968, 79) s azzal együtt a klasszikus görög embereszménynek a képlékennyé válását. Ahogyan tehát az individuum elidegenedett a közösségtől, úgy került mind közelebb az ember egzisztenciális problémáinak átéléséhez, természeti valójának és élethelyzeteinek megértéséhez, új társadalmi érzékenység formálódott ki a különböző társadalmi csoportok, lelkiállapotok, élethelyzetek megfigyelése iránt, s ez az irodalmi (pl. Kallimakhosz, Leónidasz, Theokritosz) és képzőművészeti ábrázolásokon (pl. spinario-jelenetek) egyaránt visszaköszön. A megváltozott eszmei tartalomnak és pszichikai beállítottságnak köszönhetően (Tatarkiewicz 2006) e korban élte virágkorát a gyermekábrázolás is, hiszen a lebomlóban lévő, az örök érvényü erkölcsi bizonyosságok táplálta klasszikus emberideál többé már nem jelenthette eszmei gátját a pillanatnyiságánál, esetlegességénél és természeti meghatározottságánál fogva definiált gyermekkor ábrázolásának. Sőt, az új téma mintegy fennhangon hirdette a befejezetlenségre építő új életszemlélet igéjét (French 1998, 51-52), gyakorta ironikusan kérdőjelezve meg a klasszikus társadalom- és emberszemlélet egyes toposzait, nagy szüzséit (Támba 2019, 101-122).

Ahogyan tehát a nagy ideálok hanyatlásával a müvész figyelme mindinkább az érzékenység és a tünékenység felé fordult, úgy értékelődtek fel a mindennapi élet olyan szegletei, mint a gyermekkor és a gyermeki termé- 
szet, különösen az irodalomban és a képzőművészetben. Jelen tanulmányban ezért a korszak plasztikai gyermekábrázolásainak vizsgálatára vállalkozom a gyermekkortörténeti ikonográfia-ikonológia eszközeivel (Támba 2017, 79-122; lásd még Endrődy-Nagy 2015, 35-100), az alkotások mögött rejlő eszme-, társadalom- és gyermekkortörténeti összefüggések feltárása céljából, többek közt az alkotások szövegtestébe főbb rejtett gyermekségretorikai szólamok, gyermekszemléleti mintázatok, valamint a feltárt gyermekképből kibontható emberképmotívumok feltérképezése érdekében.

\section{A késő klasszikus kor gyermekábrázolásai - felnött-gyermek kapcsolat}

Az önmagában nyugvó belső egyensúly által jellemzett pheidiaszi plasztika klasszikus zártságával szemben a késő klasszikus szobrászatban már új, oldottabb, szenvedélyesebb vizuális nyelv kezdett kiformálódni (Castiglione 1996, 61-62). Ezzel párhuzamosan a korszak szobrászatában megfigyelhető egyfajta ikonográfiai fordulat is, melynek értelmében a klasszikus embereszményt tükröző atléta- és héroszábrázolások helyett már egyre inkább a halandó, mindennapi élethez közelebb álló alakok és életesemények kerültek megjelenítésre. Ilyen téma volt a gyermekkor is, de ebből a korból még elsősorban gondozási jeleneteket, felnőtt-gyermek kapcsolatot bemutató ábrázolásokat ismerünk. Igaz ugyan, hogy ezek a jelenetek többnyire valamely mitológiai téma ürügyén kerültek megfogalmazásra, ám a gyermekről való gondoskodás megörökítése már önmagában informál minket arról, hogy a korabeli közgondolkodás egyre inkább közeledett a mindennapi élet naturális-individuális aspektusaihoz. A korszak diádikus kapcsolatot bemutató ábrázolásain már felismerhetők a gyermeklét alapvető anatómiai-fiziognómiai és lélektani sajátosságai, s a gyermekélet főbb motívumai olyan tulajdonságok lesznek, mint amilyen a gyámoltalanság, a játékosság és a szeretetre méltóság. Később, a hellenizmus korában mintha már eltünne ez a téma, hogy helyüket a gyermekkort önértékénél fogva értelmező egyalakos gyermekábrázolások (gyermekportrék és gyermekzsánerek) vegyék át, ám a késő klasszikus kor gyermekreprezentációja már mintegy átmenetként szolgált egy új korszak új ikonográfiai karaktere felé.

A késő klasszikus görög szobrászat kb. Kr. e. 430-330 közé tehetö, a korszak vége felé haladva azonban már egyre inkább a klasszikus stílus felbomlásáról beszélhetünk, gondolva itt elsősorban Lüszipposz, Szkopasz és Praxitelész munkásságára. Azonban már Praxitelész apja, Képhiszodotosz is újszerü kompozíciós megoldásokkal és ikonográfiai megfontolásokkal élve, még ha formanyelvi értelemben visszafogottabb is volt, mint kortársa, Timotheosz. 


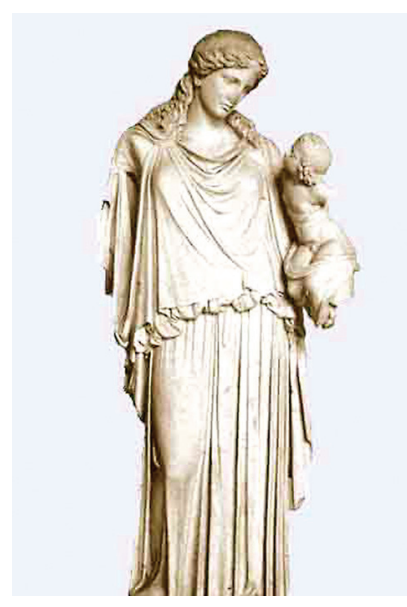

\section{1. kép. Képhiszodotosz: Eiréné a gyermek Plútosszal. Római másolat,} Athénban találták. Kr. e. 370.

Forrás: hellenicaworld.com. http://www.hellenicaworld.com/Greece/Art/Ancient/en/ KephisodotosArt.html [2020. jan. 23.]

Egyik legismertebb munkája az Eiréné a gyermek Plútosszal (1. kép) (Kr. e. 370 k.), amely eredetileg az athéni Agorán állt, s eredetije bronzból készülhetett; ma római másolatból ismerjük. A mű talán a Spárta és Athén közötti béke jegyében született. A szobor azt ábrázolja, amint a hórák egyike, a béke védnöke, Eiréné oltalmazón a bal karján tartja a kisded Plútoszt, a bőség és gazdagság istenét, aki tiszteletteljesen tekint gondviselöjére. Az istennő tekintélyét magassága is érzékelteti, s tömbszerü megformálása, ruházatának tömege, valamint a nagy tömegben aláhulló drapéria függőleges redői csak tovább hangsúlyozzák. Utóbbi megoldás a magasság, a szellemi nagyság és hatalmasság, a tekintély, valamint a statikusság érzetének elmélyítését egyformán szolgálja. A függőleges redőkhöz képest az átlós, hullámos redők ritkábbak, mindenesetre ezek érzékeltetik a gondviselői érzelmeket, az oltalmazó nevelői attitűdöt. A két alak méretbéli különbsége túlzott, $\mathrm{s}$ ami a gyermekalakot illeti, Plútosz kis méretétől eltekintve a test arányai és az anatómiai-fiziognómiai vonások is inkább egy, a gyermeki és a „miniatűr felnőtt” között félúton lévő teremtést mutatnak; a mármár atletikusnak ható felsőtest és a bölcs tekintet is inkább az utóbbi irányába hat. Ugyanakkor a gyermek itt - a felfelé irányuló tekintetnek és az arányoknak köszönhetően - meglehetősen függő, kiszolgáltatott lénynek tetszik védelmezőjével szemben.

Pauszaniasz okos ötletnek tartotta, hogy Képhiszodotosz a béke istennőjét a vagyonosság istenének dajkájaként vagy anyjaként ábrázolta, ezáltal mintegy azt sugallva, hogy a jólét fennmaradásának feltétele a béke megőrzése. Ám Eiréné 
tekintete - az oltalmazó gesztus ellenére - szomorúnak tetszik, mintha csak attól tartana, hogy a kettejük (Eiréné és Plútosz) alakja által szimbolizált béke és jólét időszaka már nem tart sokáig Hellász földjén, ahol nemrég még háborúk dúltak a hegemóniáért. A mü az anyai vagy gondozói oltalmazás mozzanatán túl tehát egy válságfélelemtől átjárt korszak kétségbeesését, melankóliáját juttatja kifejezésre, miközben magát a gyermeket mutatja fel a gazdag élet garanciáját jelentő jelképes alak gyanánt.

A plasztikus és monumentális hatást kölcsönző munkán alapvetően még érezhető ugyan a szobrászati tradíciók erőteljes tisztelete, ám újszerű vonása a münek a polükleitoszi testtartástól eltérő kontraposzt, vagyis „a test súlyát hordozó bal oldal és a[z eredetileg] jogarra támaszkodó kar széles gesztusában kinyíló jobb oldal kontraposztja" (Sarti 2007, 235). Mindenesetre Képhiszodotosz kortársa, Timotheosz már jóval szenvedélyesebb, dinamikusabb, expresszívebb szobrokat alkotott, amelyek újító törekvése már a test arányaira és kiegyensúlyozására vonatkozó újszerü megoldásokban, müveinek könnyed, dekoratív stílusában is tetten érhető (pl. az Aszklépiosz-templom dekorációi [Kr. e. 380-375]). Hozzá képest, mint a vizsgált alkotáson is látható, Képhiszodotosz jóval erősebben kötődött a hagyományokhoz.

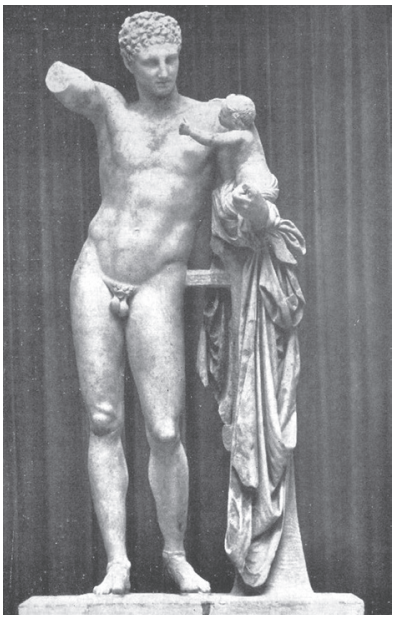

2. kép. Praxitelész: Hermész a kis Dionüszosszal az olümpiai

Héra-templom cellájából.

Kr. e. 330-320. Paroszi márvány. Magasság: 2,15 m. Olimpia, Múzeum.

Forrás: Castiglione 1968, 174.

Ugyancsak mitológiai keretek között ábrázolja a gyermekvigyázás mozzanatát a Hermész a kis Dionüszosszal címet viselö, paroszi márványból készült, 2,15 m magas szobor (2. kép) (Kr. e. 330-320), mely az olümpiai Héraionból való, s 
ma az Olimpia Múzeumban található. A mủ említésével először Pauszaniasznál találkozunk, az ő nyomán tulajdonítjuk Praxitelésznek. A szobrot, legalábbis annak római kori másolatát, 1877-ben találták meg (Castiglione 1968, 278).

A mű mitológiai háttértörténete szerint Zeusz az istenek hírnökére, Hermészre bízta újszülött gyermekét, a kis Dionüszoszt, meghagyva számára, hogy menekítse a gyermeket a nymphákhoz Héra haragja elől. Praxitelész kompozíciója éppen azt a pillanatot ábrázolja, amint Hermész útközben megpihent, s egy fatörzsnek támaszkodva játszott a karján tartott Dionüszosszal; karjáról gazdagon redözött drapéria hull alá (Castiglione 1968, 172). Másik karjában eredetileg szőlőfürtöt tartott, hogy ezzel szórakoztassa a kis istenséget, akinek gyermeki kíváncsiságáról tanúskodik, ahogyan kis kezeit a fürtök felé nyúitja. A szőlőfürt azonban ma már hiányzó darabja az alkotásnak (Sarti 2007, 236). A mü nyíltan és közvetlenül ábrázolja az érzelmeket, a felnőtt-gyermek kapcsolatot és a fáradtság állapotát egyaránt, amire a klasszikus kor művészetében nem lehetett példa, hiszen e korban a szeretetteljes felnőtt-gyermek kapcsolat elenyésző jelentőséggel bírt.

Hermész alkata a klasszikus szobrokétól eltérően nem atletikus, hanem nyúlánk, idomai lágyabbak, előkelőbbek. Nem „az emberség magasztos ideálját” nyújtja már e mü, mint Pheidiasz alkotásai, hiszen Praxitelész még istenfiguráit is emberi vonásokkal kívánta felruházni, ahogyan az a knidoszi Aphrodité címü alkotáson is tetten érhetö (Castiglione 1968, 173). Ez meglehetősen új volt e korban, ahogyan az istenek ruhátlanul történő ábrázolása is (Sarti 2007, 236), s egyáltalán, a fiatalabb istenek megformázása.

A mű kompozíciója, felépítése Praxitelész apja, Képhiszodotosz művére, az imént tárgyalt Eirénét és Plútoszt ábrázoló szoborcsoportra emlékeztet, azonban e műnél törékenyebb egyensúly jellemzi, hiszen a szobor oldalirányban kiegyensúlyozatlan, mint Praxitelész számos más, márványból faragott alkotása. Ezt a kiegyensúlyozatlanságot jelzi még a támaszték alkalmazása is. Mint Praxitelész más alkotásain, e müvön is a városállamok polgárainak megrendült identitástudata jut kifejezésre e mozzanaton keresztül, tehát az, hogy a figura külső támasztékot keres álló helyzetének megtartásához, jelzi a korabeli társadalom belső egyensúlyának megbomlását (Castiglione 1996, 62). Ez utóbbi megoldás visszaköszön majd a hellenizmus századaiban is. Az alkotást mindenesetre könnyed stílus jellemzi, finom fény-árnyék játékkal és lágyan domborodó formákkal (Sarti 2007, 236).

E szoborcsoporton a fáradtság mozzanata indokolja a játékosság megjelenítését, $\mathrm{s}$ ez a mentalitás korszakos megváltozását jelzi előre: a poliszdemokrácia válságának közepette már nem bizonyul müködőképesnek a kalokagathia eszméje, ahogyan az állandóság létélménye sem, a figyelem immár a testi-lelki 
élet természeti valóságára összpontosul, s ennek jegyében most már a gyermekkel való játék is értelmet nyer, mint a gyermek érzelmi fejlődését elősegítő tevékenység. Most már a gyermek ábrázolása is valószerü, hiszen játékosság, pajkosság, bájosság, esetlenség, gyámoltalanság jellemzi, valamint az érzelmek szertelensége. Az utóbbit főleg a szőlő után nyúló mozdulat jelzi, valamint a támasztékról nagy tömegben aláhulló drapéria.

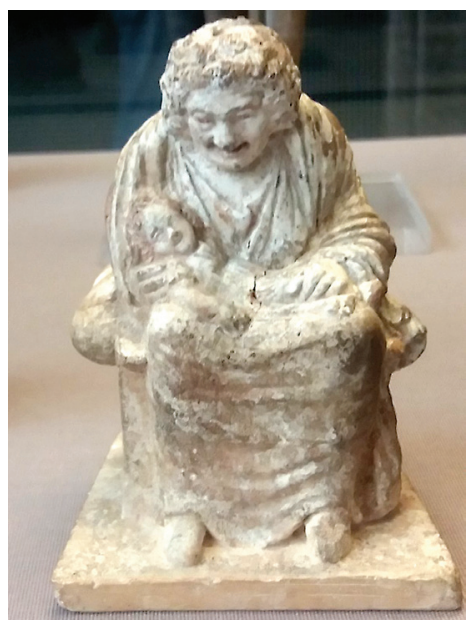

\section{3. kép. Karjaiban csecsemőt ringató öreg dajka.}

Kr. e. 330-300 k. Boiótiában találták. London, British Museum.

Forrás: a szerző felvétele

A mitológiai tárgyú ábrázolásokon túl a gondozás témájának hétköznapi élethelyzetben történő megjelenítését nyújtja a Karjaiban csecsemöt ringató öreg dajka (Kr. e. 330-300 k.) Boiótiában talált terrakottafigurája (3. kép), melyet ma a londoni British Museum őriz. Az alkotás az elmélyült személyiség- és karakterábrázolás, illetve az emberi tapasztalatok sokféleségének megnövekedett erejü művészi megragadásáról tanúskodik, kiváló érzékkel mutatva be az életkori jellemzőket. A szobrot egyszerű stílus jellemzi a józan tárgyilagosság jegyében: elölnézetre komponált, visszafogott, nyugodt harmóniát közvetítő alkotás ez, mely még magában hordja a klasszikus hagyományokat, s egyúttal emlékeztet az archaikus szobrászat hagyományaira is.

A dajka arcának reális bemutatása, illetve vaskos alakjának részletezése okán e szobor - annak klasszikus nyugalma ellenére - mégis már a naturalista személyiségábrázolás példája. A dajka vaskos orra, táskás szemei, fogatlannak ható szája kifejezetten naturális részletek, ahogyan az asszony tömzsi testalkata is. Ez azonban meglepő ellentmondásban áll a szobor beállításával, mely a klasszikus görög szobrászat nyugodt harmóniáját árasztja. Mindenesetre e szobor alkotója 
már nem az eszmék felől közelített, hanem olyannak kívánta bemutatni a dajka és dajkált gyermeke párosát, amilyennek a valóságban, a hétköznapi életben látszódott. E mü tehát mentes az egységes emberkép tükröztetésének törekvésétől, a cél itt az érzékelhető jelenségnek a maga teljességében való bemutatása, a látható részletek alapos visszaadására törekedve, nem mentesen az ábrázoltak személyiségének érzékeltetésétől sem (lásd Castiglione 1968, 219).

A tömbszerűen megformált, $s$ ezáltal a stabilitás és állandóság élményét, a biztonság és a megbízhatóság érzését árasztó dajka alakjába a drapéria redői, a ruházat viszonylag egyenes vonalú ráncai némi elevenséget visznek, ahogyan a dajka dús hajzata is, érzékeltetve az asszonyban munkáló érzelemgazdagságot. A dajka derüs arckifejezése, enyhén lefelé biccentett feje, kissé görnyedt tartása érzékelhetővé teszi a gyermekre összpontosítás mozzanatát. A dús hajzatú kisgyermek alakja pólyában jelenik meg, bábuszerüen, ábrázolása a dajka alakjához képest elnagyolt. Mindenesetre a dajka függőleges alakja és a kezében szunnyadó, bepólyált kisded vízszintese egymással kontrasztot képez, s egyúttal gyöngéd feszültséget kelt. A ringatás mozzanata és a gyermek tagjainak deformálódásának megakadályozását megcélzó pólya (lásd French 1998, 51-52) alkalmazása pedig egyaránt tájékoztat minket a gyermek lényére fordított nevelöi figyelemről. Ez már az új korszakot készíti elő, amelynek során mind jellemzőbbé válik a szeretetteljes nevelői és szülöi kapcsolat kialakulása, a gyermekhez fordulás mozzanata (Pukánszky 2001, 39; French 1998, 53-54; Fináczy 1922, 184), valamint a gyermek szeretetre méltóságáról, ártatlan voltáról alkotott felfogás (French 1998, 51).

\section{Gyermekportrék a hellenisztikus szobrászatban}

A Hellász szellemi totalitását kifejező pheidiaszi plasztika klasszikus jegyeivel szemben a hellenisztikus korszak szobrászatát az individualista-naturalista ábrázolásmód jellemezte (Hauser 1968, 73, 81), melynek gyökerei már Szkopasz kicsavarodott testü, fájdalmas arckifejezésü, mozgalmas nőalakjainál felfedezhetö (Sarti 2007, 37), vagy épp Praxitelész támasztékot kereső, kiegyensúlyozatlan figuráinál (Castiglione 1968, 173). Előbbi a pergamoni és a rhodoszi, utóbbi az alexandriai iskolára gyakorolt nagy hatást szeszélyes, dinamikus ábrázolásmódjával, ám Nagy Sándor udvari szobrásza, Lüszipposz egészen átfogó ábrázolási elveket foganatosított meg az elkövetkezendő századok szobrászata számára (Castiglione 1996, 19).

Lüszipposz az ember „tiszta eszméjéből” kiinduló alkotásmódtól eltávolodva az érzéki benyomásokból táplálkozó, az ember természeti valóságáról informáló ábrázolásmód felé igyekezett (Castiglione 1968, 211), áthelyezve őt az „igaz” és a „jó” kategóriái által működtetett platóni „állandóságból” a pilla- 
natokban való létezés köznapi közegébe (Hauser 1968,74). Apoxüomenoszával leszámolt a klasszikus szobrászat egynézetü ábrázolásmódjával, a térbenyúlás gesztusával meghódítva a tér mindhárom dimenzióját (Castiglione 1968, 193; 1996, 61-62), s ennek köszönhetően a test kilépett a klasszikus görög szobrászat állandóságélményétől meghatározott ideális térből az esetlegesség terébe. Ezt a fordulatot csak hangsúlyosabbá tette az állás és lépés közötti átmeneti mozgásállapot (Castiglione 1996, 61-62), ahogyan a kicsavarodott testtartás és a drapéria redői által keltett fény-árnyék hatás (Boardman 2007, 230), valamint a lüszipposzi kánon, mely a természetes testarányok használatával ugyancsak a természetszerüséget hangsúlyozta az értelem (a „fej”) uralkodó szerepét hangsúlyozó polükleitoszi kánonnal szemben (Castiglione 1996, 197).

Szkopasz, Praxitelész, de legfőképp Lüszipposz ábrázolási elvei a jelen dolgozat vizsgálatának tárgyát képező gyermekábrázolások kompozíciós jegyeit elemezve is felismerhetők, s e jellemzőkre mintegy ikonográfiai kódokként is tekinthetünk. A hellenizmus korának gyermekportréi azon túl, hogy dokumentálják a gyermekkor megfigyelése iránti megnövekedett igényt, s ezáltal a gyermekkor felértékelődését, s individuális voltánál fogva történő megközelítését, reflektálnak a korszak változóban lévő eszmei-pszichikai beállítódására is.

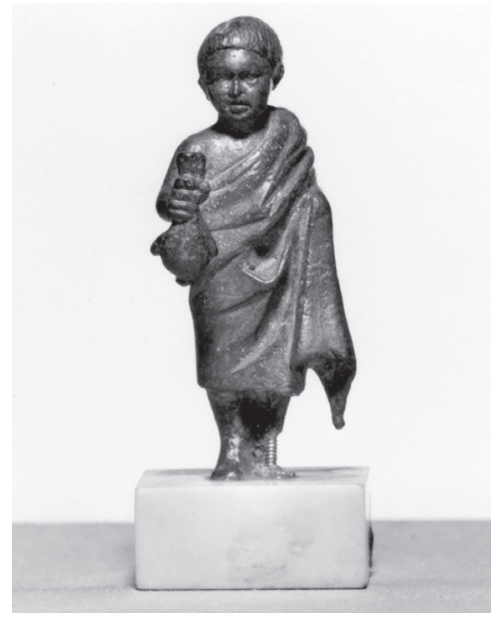

4. kép. Gyermek. Kr. e. 332-330.

Bronz. Magasság: 6,5 cm. Baltimore, Walters Art Museum.

Forrás: The Walters Art Museum. https://art.thewalters.org/detail/8008/child/ [2019. júl. 11.]

A Gyermek című, márványtalapzaton álló bronzszobrocska (4. kép) (Kr. e. 332-330; bronz; magasság: 6,5 cm; Baltimore, Walters Art Museum) szigorúan értelmezve még a késő klasszikus korban keletkezett, mindenesetre miután a test megnyújtott arányai, az állás és lépés közötti átmeneti mozgáshelyzet ábrázolása 
és a térbe nyúlás gesztusa révén a szobor már Lüszipposz örökségét mutatja a maga visszafogott módján, e művön már az új kor atmoszférája érhető tetten. A megemelt drapéria redőinek spirális csavarodása mozgalmasságot kölcsönöz a münek, az enyhén oldalra biccentett fej jelzi a gyermekkor elevenségét, akárcsak érdeklődést kifejező élénk tekintete. A mủ a gyermekkor anatómiai-fiziognómiai vonásainak gondos megfigyeléséről tanúskodik, noha az ábrázolt mozdulat az újítások ellenére még kissé szertartásosnak hat. A kisplasztika voltaképpeni témája pedig valószínűleg nem más, mint áldozatvitel (a fiú kezében egy megfojtott szárnyas jószágot visz), mely egyértelmüen a szakralitás irányába hat. Ugyanakkor a ruházat spirálisan csavarodó, hullámzó felületének szeszélyessége már megbontja a szakrális rend harmóniáját, $s$ ennélfogva érzékelteti egy rituáléktól átjárt kor válságát. Mindenesetre e mü még nyomként kíván funkcionálni egy lassanként kiüresedni látszó, de a hellén identitás organikus részét képező, szigorú, a gyermeket egy szerves kultúra egészének alávető rituáléról, felhíva a figyelmet egyúttal a görögség gyökeres átalakulására.
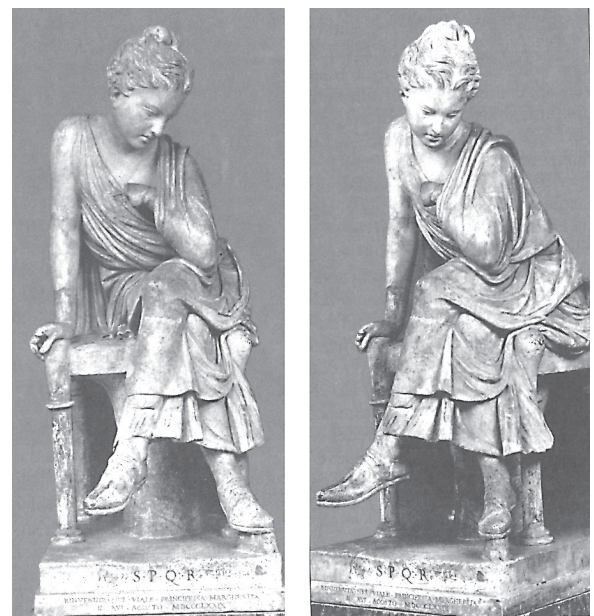

5. kép. Ülö leány. Római kori márványmásolat egy Kr. e. III. század első felében készült szobor után. Róma, Palazzo dei Conservatori.

Forrás: Castiglione 1996, 72.

A Kr. e. III. század közepe után a szobrászok már túlléptek a köznapi élet szokványos megnyilvánulásainak rögzítésén, $s$ a legbonyolultabb testhelyzeteket kezdték tanulmányozni (Castiglione 1996, 67), a testen belül lezajló mozgási folyamatok ábrázolásával mintegy birtokba véve a tér három dimenzióját (Castiglione 1996, 68). E müvek nyugtalan vibrálást fejeznek ki, akárcsak a Lüszipposz körében keletkező ülö istenszobrok (Castiglione 1996, 70), vagy épp a Lüszipposz-tanítvány Eutükhidész által készített monumentális bronzszobor, 
az antiokheiai szoborcsoport részeként ismert „Tükhé” (Castiglione 1996, 70). A piramidális kompozícióba foglalt, egyszerü körvonalakkal jellemezhető alkotás mögött roppant erőteljes belső feszültség munkál, mégpedig a vízszintes és függőleges vonalak játéka révén (Castiglione 1996, 71). Eutükhidész itt teljesen elvetette a trónolás motívumát, hiszen Tükhé keresztbe vetett lábakkal ül, előrehajló törzzsel, egyik karja lefelé nyúl, másik pedig felfelé; szembetűnő itt tehát az egymással ütköző, a tér minden dimenziójába kiterjedő komponensek megjelenítése is (Castiglione 1996, 72).

Az antiokheiai Tükhé rafinált szerkesztését követi az Ülőleány címü szobor (5. kép), amit mi egy római kori, a Kr. e. III. század első felében készült eredeti után készült márványmásolatból ismerünk (Róma, Palazzo dei Conservatori). A figura, mely mellé feltehetően egy mellékalak is készült, ez azonban nem áll rendelkezésünkre. A Tükhé kompozíciós megoldását e szobor szerkesztésmódja a végletekig kihegyezve valósítja meg, ugyanis e köznapi témánál már nélkülözendő volt a monumentális hatás. Az alkotás nem az uralkodói reprezentációt szolgálta, sokkal inkább a privát szférához tartozott, hiszen egy egyszerű széken ülő kislányt ábrázol, mintegy a zsáner nyelvére írva át, s egyúttal transzferálva mindazt, ami a trónolás fogalma kapcsán felmerül. A szék merev vonalai kiemelik az alak testének és tagjainak tartását jelző vonalakat, a leányalak komponenseinek görbületeit és diagonálisait. A leány jobb karjával a székre támaszkodik, $\mathrm{s}$ ezzel a művész meghosszabbította az alak vertikális vonalát, amelyhez a testrészek kapcsolódnak (Castiglione 1996, 72).

Az Ülő leány teljesen körbejárható, a többnézetüség elve szerint komponált alkotás, mely egy összetett mozgáshelyzetet jelenít meg. A leány felemelt kezének, a keresztbevetett lábaknak, valamint az oldalra és lefelé biccentett fejnek köszönhetően érzékelhető a mozgás pillanatnyisága, az ábrázolt testtartás szituációhoz kötöttsége. A lefelé irányuló tekintet egyúttal a befelé zárkózás lélekállapotát közvetíti a hellenizmus korának jellemző attitüdjeként, a tekintetből áradó melankólia mögött pedig mintha a kor válsághangulata munkálna.

Ideáltipikus ábrázolás helyett hétköznapi zsánerjelenetnek lehetünk itt szemtanúi, ahol az érzelmek viszonylagosságának érzékeltetése kerül előtérbe. A leány ruhájának bőven redőzött drapériája az általa eredményezett fény-árny hatással jelzi a leány érzelemgazdagságát, akárcsak hajzatának sürü, csigázott fürtjei is, s a test tengelye körül csavarodó törzs is szeszélyességre utal (Castiglione 1996, 73). Az efféle bonyolult testhelyzetek megjelenése ekkortájt vált jellemzővé. A tekintet, a ruharedők, a mozgási irányok, a mozdulatok egy csomópontban összpontosulnak, befelé építkező kompozíciót eredményezve ezáltal, érzékeltetve a kor melankolikus, introvertált atmoszféráját. A megtámaszkodás mozzanata pedig utal az érzelmi egyensúly hiányára; a külső támasz keresése, akárcsak 
Praxitelésznél, itt is a hellenisztikus világ egyensúlyának megrendülését fejezheti ki áttételes módon. Tehát itt az új, individualista-naturalista, szubjektívemocionális jellegü ábrázolásmódnak köszönhetően immár nem pusztán a leánygyermek melankolikus érzésvilága jelenik meg, ráirányítva a figyelmet az individuum sérülékenységére, hanem a lányka mikrouniverzumán keresztül ráláthatunk az őt övező makrouniverzum törékenységére is, kifejezésre juttatva a hellenisztikus monarchiákban a helyét nehezen találó individuum kétségeit.

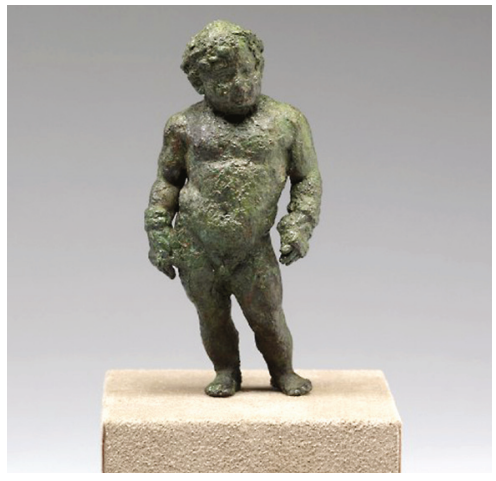

6. kép. Bokszoló gyermek. Kr. e. III-II. század, bronz.

Magasság: $8,5 \mathrm{~cm}$, szélesség: $3 \mathrm{~cm}$, mélység: $2,2 \mathrm{~cm}$.

Lelöhely: Egyiptom, Alexandria. Baltimore, Walters Art Museum.

Forrás: The Walters Art Museum. https://art.thewalters.org/detail/3131/child-boxer/ [2019. júl. 11.]

A Kr. e. III-II. század fordulójáról való a Bokszoló gyermek Alexandriában talált bronzfigurája (6. kép) (magasság: $8,5 \mathrm{~cm}$, szélesség: $3 \mathrm{~cm}$, mélység: 2,2 cm; lelőhely: Egyiptom, Alexandria; Baltimore, Walters Art Museum), mely az alexandriai realizmus stílusjegyeit mutatja. Egyenetlen, nyers felületkezelés, hússzerű megformálás, a polükleitoszi kontraposztból kiinduló, de egyensúlytalanná „fajuló” testtartás jellemzi e művet, mely utóbbi különösképpen tükrözi a hellenisztikus világ egyensúlyvesztett állapotát. E testtartás egyszerre fejezi ki a felhizlalt, birkózásra adott, s így testiségénél fogva eltárgyiasított gyermek fáradtságát és alacsony önbecsülését, ezáltal utalva a fiú nagymértékű kiszolgáltatottságára, alárendeltségére és felnőttek általi kihasználtságára. Balra biccentett feje lényének elevenséget kölcsönöz, szomorú tekintete korszakos melankóliát és hétköznapi élettragédiát egyformán sejtet. A tömzsi, hurkás tagokkal és párnás testtel ábrázolt gyermek test- és fejtartása egy méltóságát vesztett gyermek alakját nyújtja, hasonlóan naturalisztikusan, mint azt Mürón Részeg öregasszonyán tapasztaljuk (vö. Castiglione 1968, 241). Lüszipposz Apoxüomenoszához hasonlóan mintha itt is az elvégzett tett értelme fölötti mélabús meditáció mozzanatának lennénk szemtanúi; e fiú alkalmi győzelmeit felülírja társadalmi bizony- 
talansága, melynek révén szülei birkózni küldik őt a napi betevő reményében. Hiszen a kor nagy méreteket öltő társadalmi egyenlőtlenségeinek következtében a gyermekkor értéke nagyban függött társadalmi réteghelyzetétől, s ennek megfelelően a létállapotát meghatározó életesemények is determináltak voltak (lásd Pukánszky 2001, 43). Mindenesetre a capitoliumi Ökölvívó (Kr. e. III. század, 1,28 m, Róma, Museo Nazionale Romano) szobrához hasonlóan e mü is távol áll már a kalokagathia eszményétől, s itt sem a győztes önnönmagáról alkotott vágyképe vetül ki, ehelyett a bokszoló gyermek valósága a maga kíméletlen nyersességében kerül bemutatásra ezen az alkotáson (vesd össze Siebler 2008, 90). Akárcsak az Ökölvívó alakján, e szobron is roppant feltűnő a „látszatvalóság", a természeti való érzéki aspektusainak megjelenítésére való törekvés (lásd Castiglione 1968, 211; lásd Siebler 2008, 90), s mindkét mü Lüszipposz örökségének továbbviteléről tanúskodik, mégpedig az ábrázolt lelkiállapotának megragadása okán (Sarti 2007, 273).

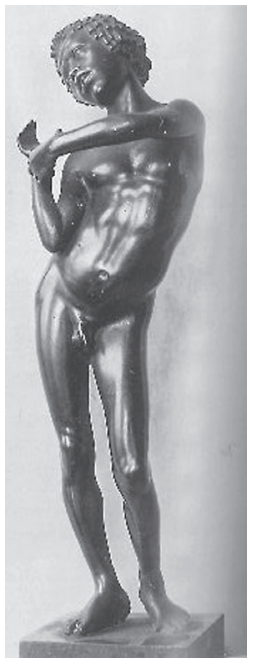

\section{7. kép. Éneklö, hangszeren játszó néger fiú bronzszobrocskája.} Kr. e. II. század. Magasság: 20,2 cm.

Forrás: Boardman 2007, 242.

A hellenisztikus korszakban jellemző volt a különböző etnikumok plasztikai rögzítése iránti érdeklődés, hiszen rengeteg törzsi nép élt a birodalmakban (Boardman 2007, 243; Castiglione 1996, 90). Ismeretes például az Éneklö, hangszeren játszó néger fiú bronzszobrocskája (7. kép) Alexandriából, a Kr. e. II. század közepéről, akinek a hangszere történetesen hiányzik; ezt jobb kezében tartotta. E kisméretű (20,2 cm magas) szobor eredetileg valamilyen terhet tarthatott, talán mécsestartóként funkcionált. A szobrocska nem véletlenül 
készült bronzból, hiszen ez adta vissza leginkább a „fényes fekete bőr hatását” (Castiglione 1996, 90), a lüszipposzi kánon követése révén pedig a művész érzékelhetővé teszi az afrikai fiú nyúlánk testének arányait. Ugyanakkor ezek a markerek - testi azonosítójegyeinek kihangsúlyozása, lényének testi adottságokra való leredukálása révén - mintegy eltárgyiasítják a néger fiút, ahogyan a mü merőben funkcionális volta is, s épp ezáltal válik igazán érzékelhetővé társadalmi kiszolgáltatottsága. Említésre méltó továbbá „a tartás rafinált ponderációja” (Castiglione 1996, 90), mely alatt a függőleges tengelytől két irányban is elhajló, már-már chiaisztikus beállítást értjük. A kompozíció a polükleitoszi kontraposztból indul ki, de az eredmény egy szeszélyes, egyensúlyvesztett állapot lesz, mely érzékelteti az ábrázolt bizonytalan társadalmi helyzetét. Az egyensúlyvesztett állapot, a némiképp groteszk ábrázolásmód okán e mü az alexandriai realizmus szobrászatát dicséri (Sarti 2007, 278).

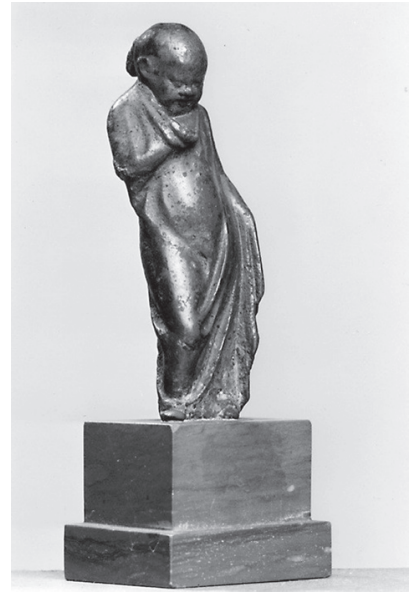

8. kép. Szónok gyermek. Kr. e. I. század - Kr. u. I. század k., bronz. Magasság: 8,6 cm. Baltimore, Walters Art Museum.

Forrás: The Walters Art Museum. https://art.thewalters.org/detail/19534/child-as-orator-2/ [2019. júl. 11.]

Lüszipposzi arányokat mutat a Szónok gyermek bronzszobrocskája (8. kép) (Kr. e. I. század - Kr. u. I. század k.; bronz; magasság: 8,6 cm; Baltimore, Walters Art Museum) is, mely datálásából következtetve az alexandriai realizmushoz köthetö, s ezt igazolja a naturális részletekben gazdag felület is. E figurán mintegy testet ölt az isokratési eszmény, mely szerint az erkölcsi és intellektuális nevelés alappillére az ékesszólásra nevelés (Hoffmann 2009, 63-64); e gondolatban fogalmazódott meg a hellén müveltségeszmény központi mozzanata, bár e szobor már a válságkor végén keletkezett. A lefelé hajtott fejjel ábrázolt, szavai értelmében elmélyült kisfiú kétértelmü, közöttes mozgásállapota, a kissé hátradőlő 
test okán előálló ingatag egyensúlyi helyzete révén érzékelhetővé válik a hellenisztikus világ válsága, de azt sejteti a himation nehézkes megemelésének mozzanata is, mely révén még szembeötlőbb a gyermek esetlensége. E mű a bukás előtti időkben még visszaidézi a hellenizmus programjának eredetéül szolgáló isokratési embereszményt, egyúttal a gyermek alakjához kapcsolva, azt sugallva, hogy a hellenizmuseszmény kiformálására leginkább a gyermek képes, nála kell elkezdeni a szónoki képességekre épülő komplex műveltségeszmény realizálását (lásd Hegyi et al. 2002, 260; Hoffmann 2009, 63-64). Azonban a birodalmi egyensúly megrendülésének melankóliája e mű atmoszférájában már egyértelmüen benne rejlik.

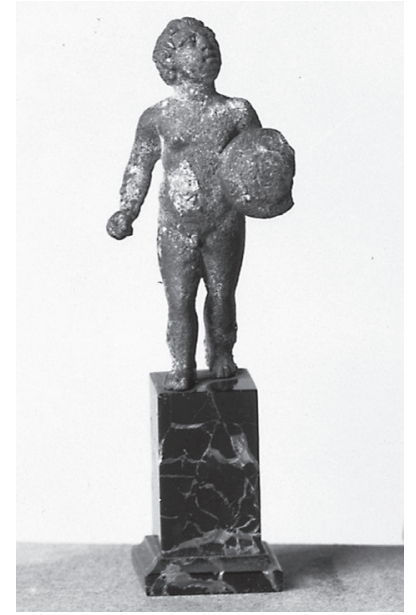

9. kép. Pajzsot hordó gyermek. Kr. e. I. század - Kr. u. I. század k., bronz. Magasság: 5,1 cm. Baltimore, Walters Art Museum.

Forrás: The Walters Art Museum. https://art.thewalters.org/detail/29361/child-carrying-a-shield/ [2019. júl. 11.]

A Szónok gyermek alakjához hasonlóan ugyancsak nyúlánk, lüszipposzi arányokat mutató fiúgyermeki testet látunk a Pajzsot hordó gyermek címü bronz kisplasztikán (9. kép) (Kr. e. I. század - Kr. u. I. század k., bronz; magasság: 5,1 cm; Baltimore, Walters Art Museum). Az egyenes tartással, kétértelmű mozgáshelyzetben ábrázolt fiú felfelé szegett feje, melankolikus, kétkedő arckifejezése, messzeségbe révedő tekintete jelzi a hellenisztikus világ válságát. A Polüektosz Démoszthenész-szobrát idéző ökölbe szorított kéz motívuma akaratos keménységet sugall, a pajzsot pedig a biztonság és a védelem jelképeként, az isteni harag vagy a harcos univerzum szimbólumaként tartja maga előtt a kisfiú, de értelmezhető a retorika attribútumaként is (lásd Pál és Újvári szerk. 2001). Az aigisz (kecskebőr) pajzs mint az ékesszólás jelentőségére felhívó szimbólum a korszak végén mintegy visszaidézi a hellenizmus eredeti, isokratési küldetés- 
tudatát a komplex hellén müveltség egyetemes mértékü elterjesztésére vonatkozóan a "helyes beszéd” eszközeivel (lásd Hoffmann 2009, 64). Ily módon e mü a Szónok gyermek párdarabjának tekinthető, hiszen mindkét darabon az isokratési eszményből kiinduló hellenisztikus műveltségeszmény megrendülése jut kifejezésre, csak míg az előbbin inkább befelé építkező, addig az utóbbin kissé szétágazóbb kompozíció keretein belül.

\section{Gyermek Erósz-ábrázolások a hellenisztikus korban}

A hellenisztikus ábrázolások jelentős csoportját képezik a legősibb istenek közé számító Erósz alakjának gyermek formájában történő megjelenítései is (Gyenge 2002). E kornak - annak az individuum problémája, s így az érzéki valóság felé forduló hajlama okán - roppant jellemző motívuma volt Erósz alakja, aki továbbra is a szerelmi vágy isteneként jelent meg, de már mentesen a platóni ideatanból fakadó értelmezéstől, mely a halhatatlanság iránti vággyal azonosította a szerelmet (Deczki 2013). Meleagrosz verseiben is a szerelmi szenvedély ,vadszívü isteneként” (Az összetört szivü szerető Erószhoz) jelenik meg a „keser-édes Erósz” (Különös eset), Moszkhosz A szökevény Erósz című versében pedig konstatálhatjuk, hogy e korban már jellegzetes attribútumává vált a szerelem könnyedségét kifejezésre juttató szárny, valamint a tegez, az íj és a nyíl. Ez utóbbiak arra szolgáltak a daimón számára, hogy szerelmi sebeket ejtsen a szíveken (Pál-Újvári szerk. 2001).

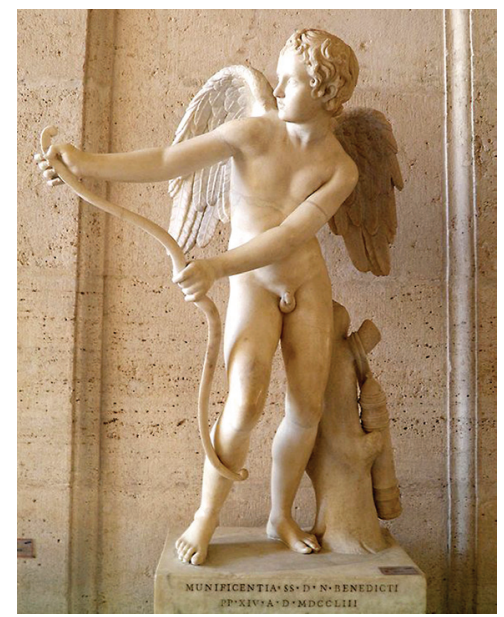

10. kép. Lüszipposz: Erósz. Római márványmásolat bronz eredeti után. Magasság: $130 \mathrm{~cm}$. Párizs, Louvre.

Forrás: Ancient History Enciclopedia. https://www.ancient.eu/image/2312/eros-stringing-his-bow/ [2019. júl. 11.] 
Szárnyakkal és íjakkal ábrázolja a serdülő-forma Erószt a legnépszerübb Erósz-ábrázolások közé számító Lüszipposz-mü, az Erósz (10. kép), melynek eredetije bronzból készült, $s$ több mint ötven másolata ismert. A Louvre-ban található, $130 \mathrm{~cm}$ magas római márványmásolat valószínűleg a káriai Mündosz számára készített darab (Kr. e. 333), melyet akkortájt rendelhettek a mestertől, amikor épp Nagy Sándort kísérte kis-ázsiai hadjáratán. A mű később Konstantinápolyba került, ahol Kr. u. 476-ban megsemmisült. A jellegzetesen lüszipposzi előadásmódban készült mű azt a jelenetet ábrázolja, amint Erósz épp leoldozza a húrt íjáról, miután célba talált vele: tehát a megsebzés utáni pillanatot mutatja be (Castiglione 1968, 280). A csigákba rendezett fürtökkel, a lüszipposzi kánon értelmében vékony, nyúlánk testtel ábrázolt Erósz íja „az ellentétes erők játékában feszül meg" (Sarti 2007, 239), a polükleitoszi kontraposzt harmóniája felől egy egyensúlyvesztett testtartás felé tendál. Alakja - Praxitelész Hermészéhez hasonlóan - támasztékot keres a térben, jelezve a poliszdemokrácia válságát, bonyolult, összetett mozdulata többnézetủ ábrázolásmódot eredményez. A kétértelmü, a mozgás és a lépés között lévő mozgásállapot, a figura merész kontraposztban történő beállítása, a széles gesztusok úttörő jelentőségűvé avatják az alkotást, mely miután - az Apoxüomenoszhoz hasonlóan - meghódította a teret, jelezte, hogy igényt tart a valóság, a természet mimetikus ábrázolására egy új, természettudományos szemléletű művészetfelfogás jegyében, szemben a platóni eidetikus művészetszemlélettel (Sarti 2007, 238).

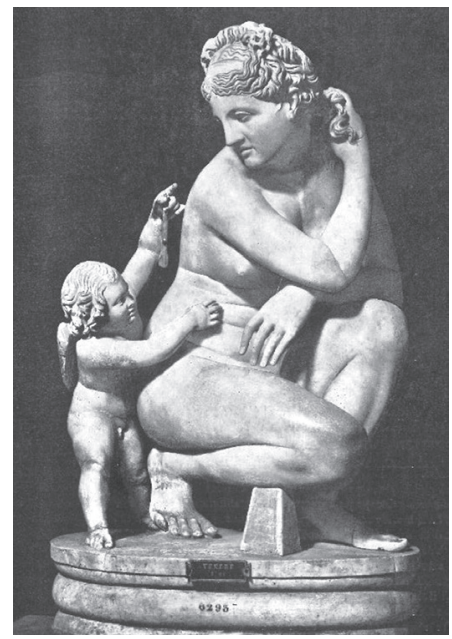

11. kép. Doidalész: Guggoló Aphrodité a fürdőben. Római márványmásolat.

(Eredeti: Kr. e. III. század közepe.)

Magasság: 1,13 m. Nápoly, Museo Nazionale.

Forrás: Castiglione 1968, 231. 
A hellenisztikus Erósz-ábrázolások jellemző típusát adja az Aphrodité oldalán megjelenő, kecses ifjúként vagy „csintalan” kisdedként megjelenített gyermekisten ábrázolása, melynek számtalan változata ismert. Számos mítosz szerint Aphrodité fia volt, Platón A lakoma című műve (pontosabban a Szókratész által megidézett Diotima) szerint viszont Porosz és Penia, vagyis a Gazdagság és a Szegénység gyermeke, aki Aphrodité ünnepi lakomáján született, s ennélfogva az istennő szolgálójává, a Szépség szerelmesévé vált (Pál-Újvári szerk. 2001). Erósz - mint a két szélsőség fia - nem más, mint félisten, daimón, aki közvetít az emberek és az istenek világa között, s közöttes abban az értelemben is, hogy se nem szép, se nem rút, nem jó és nem is rossz. Ebből a köztes állapotból fakad a vágyakozás a tudás és a szép után (Garaczi 2013, 341; Deczki 2013, 78-79; Kovács 2013, 91), a jó és a szép birtoklására való vágy pedig olyan tevékenységekkel kapcsolódik össze, mint a szülés, a nemzés és az alkotás (Deczki 2013, 80; Kovács 2013, 91), s mindhárom a halhatatlanság iránti vággyal függ össze (Deczki 2013, 80). Ennélfogva az említett ábrázolástípushoz tartozó alkotások a szépség utáni vágyakozás jelentéstartalmának hordozói. A mü mögött azonban sejteni véljük a hellenisztikus monarchiák „kisemberének” szépség és halhatatlanság utáni vágyódását is, s ezzel együtt érzékelni véljük saját tökéletlenségének felismerése fölötti melankóliáját is.

Az Aphrodité a gyermek Erósszal típusú ábrázolások sorába tartozik a kisázsiai Doidalész Guggoló Aphrodité a fürdőben címü szobra (11. kép) is a Kr. e. III. század közepéről, mely az életnagyságú bronz eredeti nyomán készült, római márványmásolat formájában maradt ránk, az eredeti változat a Kr. e. III. század közepén készült és Nikomédiában állt. Az 1,13 m magas müről számos másolat készült. Mesterét és korát Plinius Historia Naturalae című munkájából ismerjük. Elképzelhető, hogy a kis Erósz-alakot utólag csatolták az akthoz, egy későbbi változat keretein belül, de lehetséges, hogy ez is Doidalész munkája volt (Castiglione 1968, 284). A mü jelenleg a Nápolyi Nemzeti Múzeumban áll.

A guggoló Aphroditét a belé kapaszkodó, combjánál ágaskodó szárnyas Erószszal ábrázoló szoborcsoportot tömörre fogott, zárt kompozíció jellemzi, hiszen Aphrodité alakja egyetlen zárt körvonallal körülírható, s minden mozzanat és motívum (tekintet, mozdulat, ruharedők) egyetlen csomópontba, centrumba fut össze. Ugyanakkor a szemérmességénél fogva bemutatott Aphrodité alakjának zárt atmoszférájába mintha betörni igyekezne a gyermek Erósz, cselekvésre késztetve az általa csodált istennőt.

A művész itt a testen belül zajló mozgás érzékeltetésével éri el, hogy alkotása birtokba vegye a tér mindhárom dimenzióját (Castiglione 1996, 68), egy valódi körplasztikát eredményezve ezáltal. Szenvedélyességet és nyugtalan vibrálást kölcsönöz az alkotásnak, ahogyan a test merészen megcsavarodik saját tengelye 
körül (Castiglione 1996, 67), de a szeszélyes összhatáshoz járulnak hozzá az alakok hajának csigavonalai, sürü fürtjei is. Aphrodité testtartásából, idomait szemérmesen takargató mozdulataiból fakadóan jól láthatóvá válnak a test gömbölyded formái és ruganyos felületei, a hús és a bőr látványát pedig aprólékosan kidolgozott ráncok és hajlatok teszik igazán elevenné. Mindez a szexuális érzékletesség igen magas színvonalú művészi reprezentációjához vezet, amely a hellenisztikus szerelmi költemények finom erotikájával rokonítható (Castiglione 1996, 73).

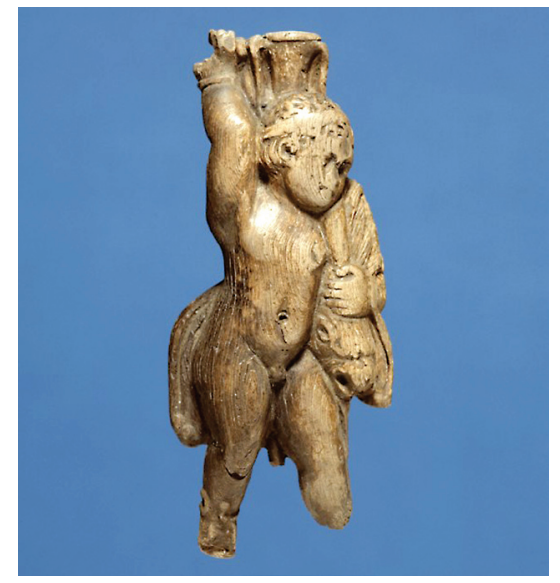

12. kép. Erósz mint a gyermek Héraklész.

Magasság: 4,18 cm. Elefántcsont. Baltimore, Walters Art Museum.

Forrás: The Walters Art Museum. https://art.thewalters.org/detail/6788/eros-as-the-child-herakles/ [2019. júl. 12.]

A szárnyak nélkül ábrázolt Erósz a gyermek Héraklészként kerül bemutatásra Erósz mint a gyermek Héraklész címen jegyzett, $4,18 \mathrm{~cm}$ magas elefántcsont kisplasztikánkon (12. kép), melyet ma a baltimore-i Walters Art Museum őriz. Erósz itt oroszlánt vet át a vállán, $s$ amforát rögzít hozzá, melynek ábrázolása pontatlan: a teteje és az alja nem igazodik egymáshoz. Erósz jobb lábán kanyargó lábdíszt, jobb csuklóján karkötőt visel, fején pánt látható. Hiányos (jobb kézfeje és talpai letörtek) és kopott állapota ellenére nyilvánvaló a figura aprólékos kidolgozása. A szobor lapos hátán bevágás és két pár lyuk található bútorhoz rögzítés céljából, a mü ugyanis eredetileg díszítő funkcióval bírt. A dekoratív funkcióval bíró gyermekábrázolások nagy számban elterjedtek a hellenizmus korában, ahogyan a vállukon amforát tartó Erósz-figurák is, ugyanakkor az elefántcsont alkalmazása már ritkaságnak számított (The Walters Art Museum). Mindazonáltal az ábrázolás legnagyobb érdekessége, hogy két istenséget egyesít magában egy gyermek alakjában, összekapcsolva egymással a Héraklész és az Erósz által hordozott tulajdonságokat, ráadásul egy gyermek alakjában. Ebből 
következtetve a mú állítása a gyermekkorról, hogy a gyermekkor az az életszakasz, amelyben egyesül egymással a testi erő, az indulat, a fáradtságos munka, a bátorság, a legyőzhetetlenség, a faragatlan modor és a mértéktelenség vonása a szerelmi és nemzési ösztön jegyével, az ösztönös teremtés és fejlődési vágy motivációjával (Pál-Újvári szerk. 2001).

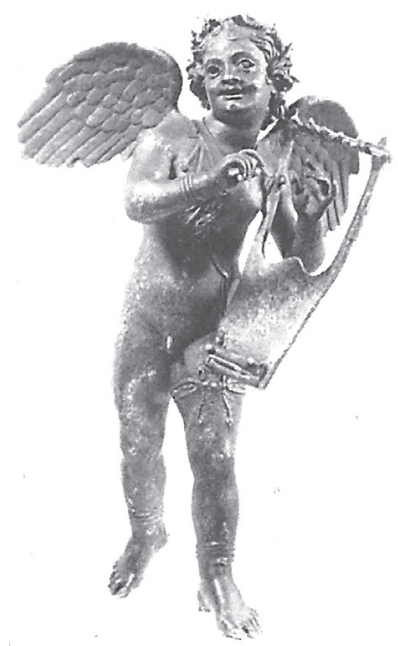

13. kép. Lanton játszó repülő Erósz bronzszobrocskája a Mahdiánál elsüllyedt hajó rakományából. Kr. e. II. század. Tunisz, Musée Alaoui.

Forrás: Castiglione 1996, 88.

A tuniszi Musée Alaoui épületében őrzött Lanton játszó repülő Erósz címü bronzszobor (13. kép) egy görög mütárgyakat szállító, Mahdiánál elsüllyedt hajó rakományából került elő, mely Itália felé tartó útján elsüllyedt. A szobrocska a kor válságperiódusából való, a Kr. e. II. századból, s akárcsak a számtalan hozzá hasonló figura, immár nem sírok vagy szentélyek, hanem a privátszféra számára készült, magánházakban és női lakosztályokban képzelhetjük el egykori valós rendeltetési helyét. A szétágazó karok és lábak mozzanata révén érvényesül itt a centrifugális szerkesztés elve (Castiglione 1996, 82), melynek még jobban érvényt szerzett, hogy felfüggesztésre szánták, s így valósággal lebegett a térben (Castiglione 1996, 8). Erósz itt lanttal a kezében került ábrázolásra, mely a szépre törekvés, az esztétikai alkotás vágyát jelképezi, a szárny pedig a szerelem könnyedségét juttatja kifejezésre (Kovács 2013, 91; Pál-Újvári szerk. 2001). Alakjában tehát összekapcsolódik egymással a szerelem, az alkotás és a halhatatlanság jelentése (Deczki 2013, 80), az ezek utáni vágyódás élménye, de Orpheusz története révén ezen alak a harmónia, a természeti erők megbékélésének szimbóluma is lehet (Pál-Újvári szerk. 2001). 


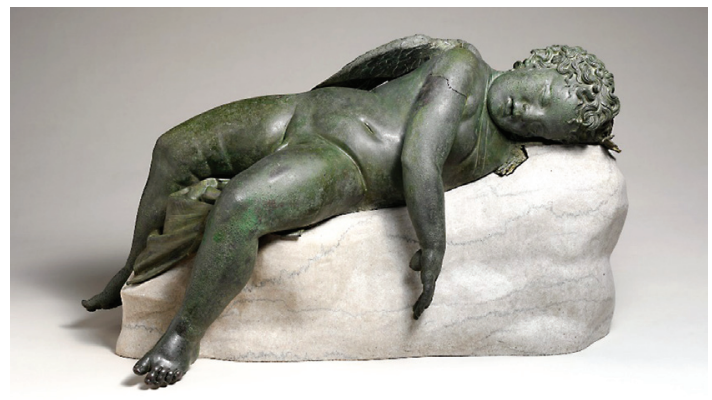

14. kép. Alvó Erósz. Kr. e. II. század. Bronz. A sziklatalapzat modern kiegészítés. Magasság: 45,7 cm. New York, Metropolitan Museum of Art.

Forrás: The Metropolitan Museum Of Art. https://www.metmuseum.org/toah/works-of-art/43.11.4/ [2019. júl. 20.]

Az Erósz-ábrázolások legnépszerübb darabjai közé tartozik a Metropolitan Museumban őrzött, a Kr. e. II. századból való, 45,7 cm magas Alvó Erósz címü bronzszobor (14. kép) (The Metropolitan Museum of Art, é. n.), melynek jelenlegi talapzata modern kiegészítés, eredeti alapja kőből készülhetett. A fegyvertelenül fekvő gyermek Erósz kövérkés testének naturális részletekben gazdag, érzékletes, ugyanakkor szentimentális hangú ábrázolása (Castiglione 1996, 85) távol áll az archaikus költészet Erószának kegyetlen és szeszélyes lényétől, sokkal inkább a gyermeki ártatlanság toposzát hordozza magában.
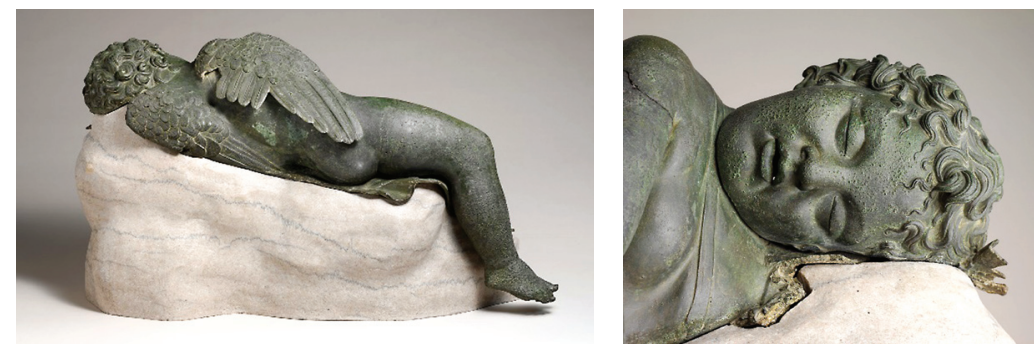

A kisded pufók arcának, párnás testének, hurkás tagjainak aprólékos ábrázolása a gyermekkor anatómiai-fiziognómiai vonásainak alapos művészi obszervációjáról tesz tanúbizonyságot; a mű alapjául feltehetően valódi modell szolgálhatott, ami a hellenizmus korában már jellemző volt. A gyermek puhának tetsző karjai és lábai már-már formálhatónak tünnek, ami azt a benyomást kelti, mintha e formálhatóság a korabeli pedagógiai gondolkodásnak a gyermeki személyiség és karakter alakíthatóságáról vallott nevelésfelfogását hordozná magában, amely számára az anatómiai értelemben vett alakíthatóság analógia gyanánt szolgált az ógörög időkben. Ugyanakkor ehhez a felfogáshoz kapcsolódóan a mü magában hordozza a gyermek tudatlanságáról, erkölcsi érintetlenségéről és derűs voltáról 
alkotott korabeli elképzelést is (French 1998, 51), amelyet az álomba szenderült gyermek Erósz öntudatlanságot sugalló gondtalan arckifejezése csak megerösít.

A fennmaradó replikák nagy számából ítélve az alvó Erósz típusa roppant népszerü volt a hellenizmus korában, amikor e szobrokat többek közt felajánlásként készíthették Aphrodité istennő tiszteletére, s az ő szentélyein belül kerültek elhelyezésre, esetleg még nyilvános parkokban, királyi vagy magánkertekben találhatták meg helyüket. Ugyanakkor még népszerübbek voltak ezek az ábrázolások a római időkben, amikor a római villák kertjeinek és szökőkútjainak díszítését szolgálta (The Metropolitan Museum of Art, é. n.). Ám miután az alvás a görög mitológiában gyakran a halál jelentését hordozta magában, az álomba szenderült Erósz figurája akár síremlékhez is tartozhatott, mint jelen esetben is.

Ehhez képest az alvó szatírt bemutató Barberini faun (Kr. e. 220 k.) bortól kábultan, pőrén és illetlenül fekvő alakja az öntudatlanság egészen más változatát tárja elénk: e részeg suhancot mintha elhagyta volna szelleme, hogy bestiális ösztönvalója uralja el testét, arcát bormámor és fáradtság tölti el (Castiglione 1996, 85). Alakja immár nem képviseli a kiegyensúlyozottság, az öntudatosság és a fegyelem értéke által meghatározott klasszikus görög emberképet (Castiglione 1968, 224), ehelyett szertelenség és öntudatlanság által átjárt lénye már a hellenisztikus birodalmak egyensúlyának megrendülését jelzik. A bor istenének bujaságot árasztó alakjával szemben azonban az alvó Erósz figurája az érzékiség, a szexualitás és a halál összefonódásának költői szintű megfogalmazását nyújtja.

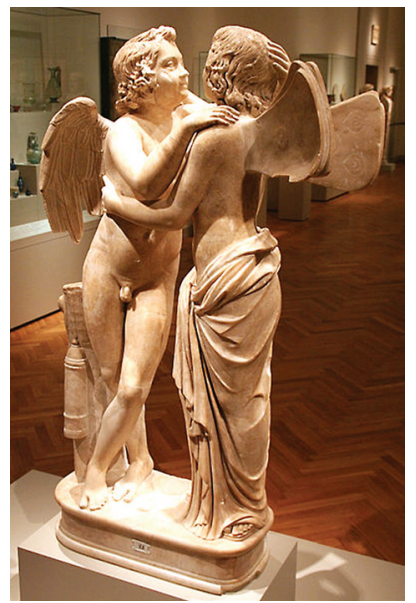

15. kép. Erósz és Pszükhé (Daphniszés Khloé vagy A csók felfedezése).

Kr. e. 150 k. Római márványmásolat a Kr. e. I. század végéröl. Berlin, Altes Museum.

Forrás: Wikimedia. https://commons.wikimedia.org/wiki/File:Altes_Museum_-_Statuengruppe,_ Amor_und_Psyche.jpg. [2019. aug. 24.] 
A Guggoló Aphroditéhez hasonlóan kétalakos Erósz-ábrázolás a római márványmásolatból ránk maradt Erósz és Pszükhé (Daphniszés Khloé vagy A csók felfedezése; római márványmásolat a Kr. e. I. század végéről; Berlin, Altes Museum) (15. kép), mely Kr. e. 150 körül keletkezett. A mủ mitológiai háttértörténete szerint Erósz a lélekre, a gyakran pillangó formájában ábrázolt Pszükhére vágyakozik, ő az ő szerelme. A két alak szárnya a szerelem mindenek fölött való szabadságát szimbolizálja, a könnyedség, az akarat, a szabadság jelképe. Erósz lábánál tegez látható ijakkal, jelezve rendeltetését. A két alak gyöngéden átkarolja egymást, az első csókra készülve. Pszükhé derekán a drapéria bőséges redői jelzik az érzelemgazdagságot, az alakok dús, csigákba rendezett haja is elevenséget, fiatalságot sugallanak.

Végül szögezzük le, hogy a hellenizmusra nézve rendkívül jellemző az Erószfigurák elszaporodása, hiszen ezek az ábrázolások nem mást juttattak kifejezésre, mint a korszak szertelen érzésvilágát és az individualizmus irányába tendáló pszichikai beállítottságát. Az Erósz-figurák szertelensége és a mögöttük húzódó nyugtalan, kavargó érzelmek már egyértelmüen az új korszak emberének pszichikai nyugtalanságát tükrözik. Ráadásul e „gyermekisten” köztes, átmeneti állapota révén ezekben az ábrázolásokban voltaképpen nem más ölt testet, mint a korabeli individuum sóvárgása a szépség, a tudás és a halhatatlanság iránt (Deczki 2013, 80), hogy ezen reménytelen vágyakozás által nyilvánvalóvá váljék a halandó ember életének illékonysága. Az Erószt ábrázoló müalkotások mögött tehát észre kell vennünk a hellenisztikus nagyvilág „kisemberének” hiábavaló vágyakozását a teljességre, e mögött pedig saját mulandóságának és tökéletlenségének észlelt vagy csupán sejtett, de kiábrándító valóságát.

\section{Összefoglalás}

A hellenizmus korának szobrászatában igen nagy számban jelent meg a gyermekkor témája, ezen életszakasz minden lélektani, fiziognómiai-anatómiai aspektusainak érzékeltetésével együtt. A korábbi eidetikus művészetszemlélettel szemben az új korszak képzőművészetének individualista-naturalista ábrázolási jellege tette lehetővé az új ikonográfiai téma megszilárdulását, mind az életkép (lásd Támba 2019, 101-122), mind pedig a portré müfaján belül. Az ábrázolások egy jelentős csoportját a hétköznapi gyermekportrék jelentik, egy másik csoportját adják viszont azok az ábrázolások, melyek a korszak egy-egy eszményét kívánják kifejezésre juttatni (pl. Szónok gyermek), a harmadik csoportot pedig az Erósz-ábrázolások teszik ki, továbbá még a késő klasszikus kor termései közt tartunk néhány, a felnőtt-gyermek kapcsolatot tematizáló, nagyrészt mitológiai tárgyú alkotást. 
Jelen dolgozatban 15 mü bemutatására vállalkoztam, mintegy folytatva a Tanulmányok 2019/1. lapszámában közölt, a hellenisztikus gyermekéletképekkel foglalkozó írásom témáját. Az elemzések végére érve megállapíthatjuk, hogy a hellenisztikus gyermekábrázolásokban érzékelhetővé válik a hellén kultúra individualizálódása és természettudományos szemléletűvé válása, s ebben a korábbi poliszdemokrácia rendíthetetlen eszmei egységének megrendülése jut kifejezésre. Ezek a gyermekábrázolások tehát - túl a gyermeki vonások megjelenítésén - immár magukban hordozzák a korszak megváltozott pszichikumát és társadalmi attitüdkészletét is, gyakran egyúttal közvetítve a hellenisztikus monarchiákban élő emberek általános válsághangulatát, kétségeit és melankolikus érzésvilágát.

\section{Irodalom}

Bengtson, Hermann. 2009. A hellenisztikus világkultúra. Szeged: JATEPress.

Boardman, John. 2007. Görög müvészet. Budapest: Glória.

Castiglione László. 1968. Görög müvészet. Budapest: Corvina.

Castiglione László. 1996. Hellénisztikus mủvészet. Budapest: Corvina.

Deczki Sarolta. 2013. A földi szerelemről. In Laczkó Sándor szerk. Lábjegyzetek Platónhoz 11.: A szerelem. 79-85. Szeged: Pro Philosophia Szegediensis Alapítvány - Magyar Filozófiai Társaság - SZTE BTK Filozófia Tanszék - Státus Kiadó.

Endrődy-Nagy Orsolya. 2015. A reneszánsz gyermekképe: A gyermekkép reneszánsza 1455-1517 között Európában. Ikonográfiai elemzés. Doktori disszertáció. Budapest: ELTE Eötvös Kiadó.

Falus Róbert. 2005. Az antik világ irodalmai. Budapest: Neumann Kht. http://mek.niif. hu/04700/04714/html/index.htm (2019. aug. 12.)

Fináczy Ernő. 1922. Az ókori nevelés története. Budapest: Hornyánszky Viktor.

French, Valerie. 1998. A gyermek hatásának története: ókori mediterrán civilizációk. In A gyermekkor története - szöveggyüjtemény, szerk. Vajda Zsuzsanna-Pukánszky Béla. 42-66. Budapest: Eötvös József Kiadó.

Garaczi Imre. 2013. Erósz játékai. In Laczkó Sándor szerk. Lábjegyzetek Platónhoz 11.: A szerelem. 340-345. Szeged: Pro Philosophia Szegediensis Alapítvány - Magyar Filozófiai Társaság - SZTE BTK Filozófia Tanszék - Státus Kiadó.

Gyenge Zoltán. 2002. Erósz - és ami vele születik. Pro Philosophia Füzetek 2. http://www. c3.hu/ prophil/profi022/gyenge.html. (2019. aug. 20.)

Hauser, Arnold. 1968. A müvészet és az irodalom társadalomtörténete 1. Budapest: Gondolat. Hegyi Dolores-Kertész István-Németh György-Sarkady János. 2002. Görög történelem a kezdetektöl Kr. e. 30-ig. Budapest: Osiris.

Hoffmann Zsuzsanna. 2009. Antik nevelés. Veszprém: Iskolakultúra. 
Támba Renátó: Nevelési jelenetek, gyermekportrék és Erósz-figurák...

Kovács Dániel. 2013. Túl Erószon és túl Agapén: Beszéd a szerelemről. In Laczkó Sándor szerk. Lábjegyzetek Platónhoz 11.: A szerelem. 86-98. Szeged: Pro Philosophia Szegediensis Alapítvány - Magyar Filozófiai Társaság - SZTE BTK Filozófia Tanszék - Státus Kiadó.

Long, Anthony Arthur-Sedley, David N. 2014. A hellenisztikus filozófusok. Budapest: Akadémiai Kiadó.

Németh András. 2004. Az ember - és „világának” változásai. In Németh András-Pukánszky Béla. A pedagógia problématörténete. 11-98. Budapest: Gondolat.

Pál József-Újvári Edit szerk. 2001. Szimbólumtár. Budapest: Balassi Kiadó. http://www. balassikiado.hu/BB/netre/Net_szimbolum/szimbolumszotar.htm\#Er\%C3\%B3szAmor. (2019. aug. 16.)

Panofsky, Erwin. 1998. Idea: Adalékok a régebbi müvészetelmélet fogalomtörténetéhez. Budapest: Corvina.

Pukánszky Béla. 2001. A gyermekkor története. Budapest: Műszaki Könyvkiadó.

Pukánszky Béla. 2004. Fejezetek a gyermekkor és a családi nevelés történetéböl. In Németh András-Pukánszky Béla. 2004b. A pedagógia problématörténete. 259-330. Budapest: Gondolat.

Sarti, Susanna. 2007. Görög müvészet. Budapest: Corvina.

Siebler, Michael. 2008. Görög müvészet. Budapest: Vince.

Támba Renátó. 2017. Gyermekkor a vásznakon: A dualizmuskori gyermekszemlélet az alföldi iskola festészetében. Budapest: Storming Brain.

Támba Renátó. 2019. Gyermekjelenetek a hellenisztikus görög szobrászatban. Tanulmányok 1. 101-122.

Tatarkiewicz, Władisław. 2006. Az esztétika alapfogalmai. Budapest: Kossuth Kiadó. https:// www.tankonyvtar.hu/hu/tartalom/tamop425/2011_0001_654_tatarkiewicz/adatok. html (2019. jún. 28.)

The Metropolitan Museum of Art (é. n.): Bronz Statue of Eros Sleeping. The Metropolitan Museum of Art. https://www.metmuseum.org/toah/works-of-art/43.11.4/. (2019. júl. 20.)

The Walters Art Museum (é. n.): Eros as the Child Herakles. The Walters Art Museum. https:// art.thewalters.org/detail/6788/eros-as-the-child-herakles/. (2019. júl. 12.)

Zamarovsky, Vojtech. 1980. A görög csoda. Budapest: Madách.

\section{Renato TAMBA}

\section{VASPITNE SCENE, PORTRETI DECE I LIKOVI EROSA U POZNOJ KLASIČNOJ I HELENISTIČKOJ SKULPTURI}

U svom radu želim da predstavim dečje portrete helenističke grčke skulpture, dečje likove Erosa i žanrovske prikaze dece koji pokazuju dijadski odnos i obrasce stavova iza dela, s namerom da istražim glavne momente istorije detinjstva, društva i ideja. U svom istraživanju koristim metodološka sredstva dečje istorijske ikonografije, pored ikonografsko-ikonološkog modela Panofskog, u ovom slučaju uglavnom potvrđujući Šnajderov pristup društvenoj istoriji, 
uzimajući u obzir analitičke aspekte vizuelne antropologije, vizuelne sociologije i vizuelne komunikacije. Cilj istraživanja je - kao nastavak mog rada pod nazivom „Predstavljanje Dece u helenističkoj grčkoj skulpturi“ objavljenog u Studijama 2019/1 (Tamba 2019, 101-122) da mapiram ideološko-društvena značenja i kulturne reference koje prenose predstavljanje dece u ovom periodu a odnose se na delovanje novog filozofskog senzibiliteta na probleme pojedinca.

Ključne reči: helenizam, pristup detetu, ikonografija-ikonologija, individualističko-naturalistički prikaz, dečji portret

\section{Renátó TÁMBA}

\section{EDUCATIONAL SCENES, CHILD PORTRAITS AND EROS FIGURES IN LATE CLASSICAL AND HELLENISTIC GREEK SCULPTURE}

In my study, I aim to present children's portraits of Hellenistic Greek sculpture, children's figures of Eros, and genre-like children's depictions showing a dyadic relationship, the patterns of attitudes behind the works, in an effort to explore the main voices of the history of childhood, society and ideas. In my paper, I use the methodological tools of childhoodhistorical iconography, in addition to Panofsky's iconographic-iconological model, in this case mainly validating the Schneiderian approach to social history, taking into account the analytical aspects of visual anthropology, visual sociology and visual communication. The aim of my study is - as a continuation of my paper titled "Representations of Children in the Hellenistic Greek Sculpture” published in the Studies 2019/1 (Támba 2019, 101-122) - to map the ideological-social meanings and cultural references carried by the child representations of the period, which refer to the work of a new philosophical sensitivity to the problems of the individual.

Keywords: Hellenism, child approach, iconography-iconology, individualist-naturalist representation, child portrait 